\title{
Konaklama Arz Yapısı Bakımından Turistik Destinasyonlarda Dış Çevre Analizi: Ayvalık Örneği
}

\author{
External Environmental Analysis in Tourist Destinations in Terms of \\ Accommodation Supply Structure: The Case of Ayvalık
}

\author{
Dr. Öğr. Üyesi Muammer BEZİRGAN (iD), Taner KÖMÜR (D2
}

\begin{abstract}
$\ddot{O} z$
$\mathrm{Bu}$ araştırmanın amacı, bölgede faaliyet gösteren konaklama işletmeleri açısından Ayvalık destinasyonunun dış çevre analizinin yapılmasıdır. Ayvalık turizm sektörü verilerinin incelenmesiyle birlikte turizm pazarının yapısı, sınırları ve pazarın gelişme hızı belirlenmiştir. Buna ek olarak rekabet analizi ile rakip analizleri yapılmıştır. Araştırmada, ikincil veri kaynaklarından yararlanılmıştır. Ayvalık, Türkiye'nin en büyük Doğa ve Tabiat Parkına sahip olmasının yanı sıra zeytin ve zeytinyağıyla Türkiye'de ve Dünya'da tanınmış markalardan biridir. Ayvalık'ta turizm işletme ve belediye belgeli toplam 291 adet konaklama tesisi bulunmaktadır. Ancak bu tesislerin sadece 22'si turizm işletme belgelidir. Bu noktada bölgede turizm işletme belgeli tesis sayısı oldukça azdır. Bu verilere göre Ayvalık'n bugüne kadar turizm potansiyelini hedeflediği düzeyde değerlendirememesi, turizm işletme belgeli tesis yatırımı ihtiyacına işaret etmektedir. Gerçekleştirilen bu araştırma sonucunda bölgedeki turizm faaliyetinin artış eğilimi gösterdiği; bölgeyi ziyaret edenlerin \% 20'sini yabancı turistler oluşturduğundan pazarın iç turizm ile sınırlandırılmış olduğu; bölgedeki arsa sıkıntısı ile kalifiye personel bulmanın zor olması, pazara girişteki başlıca engellerin olduğu; çok sayıda konaklama tesisi arasında tam rekabet piyasa koşullarının hakim olduğu; az sayıdaki tedarikçi arasında yeterince rekabet oluşmadığından tedarikçilerin gücünün yüksek ve çok sayıda konaklama tesisini seçebilme şansı olduğundan müşteri gücünün yüksek olduğu bulunmuştur.
\end{abstract}

Anahtar Kelimeler: Konaklama arz yapısı, dış çevre analizi, destinasyon, Ayvalık

Makale Türü: Araştırma

\begin{abstract}
The aim of this study is to conduct an external environmental analysis of Ayvalık as a destination in terms of its accommodation facilities. The nature of tourism market, borders of the market and the development speed of the market have been examined through Ayvalık tourism sector data. In addition to this, competition and competitor analyses have been done. This study has benefited from secondary data sources. Along with having the largest nature park of Turkey, Ayvalık is one of the well-known brands with its olive and olive oil in Turkey and the world. There are all together 291 accommodation facilities in Ayvalık but only 22 of these facilities have a tourism establishment certificate which shows the facility has met certain standards. According to this data, that Ayvalık hasn't been able to benefit from its tourism potential to the level intended, which indicates that it should be invested in accommodation facilities having tourism establishment certification. This study has found that tourism in the region is on the rise as the rate of foreign visitors coming to the region is about $20 \%$, the market is confined to domestic tourism; main market barriers are difficulty of hiring qualified personnel and land shortage; there is a perfect competition market among the numerous accommodation facilities; as there is no competition among the few suppliers, the power of suppliers is high and as there is many options where to stay for customers among the numerous accommodation facilities, the power of the customer is high.
\end{abstract}

1BBalıkesir Üniversitesi, Burhaniye Uygulamalı Bilimler Yüksekokulu, bezirgan@ @alikesir.edu.tr.
${ }^{2}$ Balıkesir Üniversitesi, Sosyal Bilimler Enstitüsü, taner.komur@kulturturizm.gov.tr.

Atıf için (to cite): Bezirgan, M. ve Kömür, T. (2019). Konaklama arz yapısı bakımından turistik destinasyonlarda dış çevre analizi: Ayvalık örneği. Afyon Kocatepe Üniversitesi Sosyal Bilimler Dergisi, 22(1), 295-311. 
Keywords: Accommodation supply structure, external environment analysis, destination, Ayvalık

Paper Type: Research

\section{Giriş}

Bacasız sanayi olarak isimlendirilen turizm, ülkemizde son senelerde gösterdiği kayda değer bir artışla önemli bir gelişim göstererek ekonominin en fazla döviz girdisi getiren sektörlerinden biri haline gelmiştir (Bedük vd., 2007, s. 136). Bu kadar hızlı bir şekilde büyüyen, değişen, sürekli değişimler yaşayan ve globalleşen turizm piyasalarında ayakta kalmanın, yaşamını devam ettirebilmenin veya rakiplere karşı üstünlük kazanmanın tek çaresi rekabet bakımından üstün bir konuma sahip olmaktır (Özdemir ve Yılmaz, 2016, s. 75). İşletmeler rekabet üstünlügünü elde etmek ve sürdürülebilir rekabet avantajına sahip olmak için rekabete etki eden faktörleri bilmeli ve bu faktörleri kendine fayda sağlayacak şekilde kullanmalıdırlar (Coşar, 2006, s. 4). Rekabet, bir var olabilme savaşıdır. Kıyaslama ile sağlanacak bilgiler, işletmelerin sektörlerindeki gelişim seviyeleri konusunda bilgilenmelerine ve bilhassa rakip işletmelerden daha kaliteli ürün ve hizmet üretebilme konusunda adım atmalarına yardımcı olacaktır. Bu sebeple turizm sektöründeki işletmelerin kısa ve uzun süreli rekabet stratejileri uygulamaları bir gereklilik haline gelmiştir (Zengin ve Uyar, 2012, s. 17). Hızla değişen rekabet koşulları, işletmelerin strateji oluşturma aşamasında hem iç çevre hem de diş çevre analizi konusuna daha fazla önem vermelerine neden olmuştur.

İşletmeler birbirleri ile etkileşim halinde olan geniş bir çevre içinde yer almaktadırlar. İşletmeler ekonomik sistem içerisinde işlevlerini yerine getirirken, farklı çıkar ve beklentileri olan gruplarla etkileşim içinde olurlar. Bu grupların birbirleri ve kendileri arasındaki ilişkileri işletmenin iç ve dış çevresini oluşturur. Çevreler, işletmelerde belirleyici etki yapar ve işletmelerin hangi yolu izleyeceklerini ortaya koyarlar (Güçlü, 2003, s. 72). Stratejik yönetimin evrelerinden biri olan dış çevre, işletmenin kontrolü dışındaki faktörlerden oluşmaktadır. İşletmelerin dış çevrelerinde; devlet ve kanunlar, tüketiciler, toplum yapısı ve kültürü, rakipler, tedarikçi işletmeler ve diğer işletmeler yer alır. Birçok işletme dış çevresinde yaşanan karmaşık ve gittikçe yorumlanması zor hale gelen küresel değişkenlerle karşı karşıyadır (Yılmaz, 2012, s. 45). İşletmenin kontrolünde olmayan faaliyetler onun için firsat ve tehditleri yaratmaktadır. Bu fırsat ve tehditleri ortaya çıkarmak için yapılan dış çevre analizinin unsurları; gözden geçirme, takip etme, tahmin etme ve ölçmedir. Gözden geçirme, dış çevrede ortaya çıkabilecek değişim işaretlerinin araştırılmasıdır. Takip etme, devamlı gözlemleyerek çevredeki değişikliklerle ilgili önemli tespitler yapabilmektir. Tahmin etme, gözlemlenilen değişimlere ilişkin beklenilen neticeler ve gelişim düzeylerini öngörmedir. Ölçme ise, çevreyle ilgili önemli değişiklik ve eğilimlerin ne zaman olacağının tespit edilmesidir (Güripek, 2013, s. 21).

Yapılan alan yazın taramasında turizm alanında dış çevre analizinin uygulandığı çalışmalara çok fazla rastlanılmamıştır. Turizm dışındaki alanlarda şu çalışmaların yapıldığ görülmüştür: Ofluoğlu, Arslan ve Aydemir (2006), gerçekleştirdikleri araştırmada işletmelerin stratejilerine karar verirken halihazırdaki durumunu incelemenin dışında, dış çevre unsurlarını da iyi bir biçimde göz önüne alarak bu unsurlarda ortaya çıkan değişikliklere de uyum gösterebilecek esnek bir işletme şekli geliştirmeleri gerektiği sonucuna ulaşmıştır. Yiğit ve Yiğit (2012), gerçekleştirdikleri çalışmada dış çevre faktörlerinin değişik büyüklüğe sahip işletmeler açısından etkisini araştırmış ve rekabet çevresinde potansiyel rakipler ile ikame ürünlerin tehdidi, tedarikçilerin ve müşterilerin sahip olduğu pazarlık gücünün işletmelerin boyutuna göre farklı olduğunu; rakipler arası rekabet derecesinin ise bir değişim göstermediği sonucunu ortaya çıkarmıştır. Koçoğlu ve Serinkan (2012), makalesinde Türkiye'de Yükseköğretimin farklı kriterler bakımından Dünyada sahip olduğu konumunu tespit etmeyi, şu anki durumunu analiz etmeyi amaçlamış ve Türkiye'deki Yükseköğretim'in Dünya sıralaması açısından geri durumda olduğu sonucunu bulmuştur. Bayın (2014), yaptığı incelemede sağlık kurumunun dış çevresini tanımlamayı ve dış çevre analizini sistem yaklaşımı bakışıyla açıklamayı amaçlamıştır. Ve sistem yaklaşımının, bu kurumlara dış çevrenin kontrol edilebilirliği getirdiğini; geri bilgi akışı 
ile sağlık hizmetlerinin aralıksız sunulmasını sağlayarak çıktıdan girdi safhasına kadar doğru bir bilgi alışverişini temin ettiği sonucunu elde etmiştir.

Bir önceki paragrafta bahsedilen Türkçe alan yazın taramasının yanı sıra yabancı alan yazın taraması yapılmıştır. Bu taramada ulaşılan turizm alanındaki çalışmalardan Dwyer, Edward, Mistilis, Roman ve Scott (2009), yaptıkları araştırmada politik, ekonomik, sosyal, teknolojik, demografik, ekolojik olmak üzere 6 global faktörün; gelecekteki turizm arz ve talebi belirleyeceğini, düzensizliğin arttığı ve hızlı değişimlerin olduğu Dünyada iç ve dış çevre şartlarının sebep olduğu yenilikçilik ve kalkınmanın devam edeceğini ama stratejilerini çevresini dikkate alarak belirlemeyen destinasyonların ve işletmelerin rekabet avantajı sağlayamayacakları sonucunu bulmuştur. Voiculet, Belu, Parpandel ve Rizea (2010), gerçekleştirdikleri çalışmada işletmeyi etkileyen temel değişkenleri belirlemede diş çevre analizinin etkili olduğu ve bu analizin uygulanacak stratejiler ile politikaların seçiminde önemli olduğu sonucunu ortaya çıarmıştır. Türkay, Solmaz ve Şengül (2011), yaptıkları incelemede konaklama tesislerinin dış çevre analizinde bilgiye sırasıyla teknolojik çevre, turistler ile yasal çevre yoluyla ulaştıklarını ve müşteriler, internet, bölgedeki rakipler ile çalışanlarının da çoğunlukla önemli bilgi sağlama kaynakları olduğunu bulmuşlardır. Ayrıca Konaklama tesisleri bakımından sırasıyla belirtilen bilgilerin çok büyük öneme sahip olduğu sonucuna ulaşmışlardır. $\mathrm{Bu}$ bilgiler; bilgisayarlaşma oranları, oteller için geliştirilen otomasyon sistemleri, turistlerin otelden memnuniyet düzeyleri, rakiplerin pazar payı, rakiplerin müşteri profilleri, toplantı salonlarında kullanılan sistemler, bölgesel gerginlik ve terör saldırıları, turistlerin alım gücü, turistlerin otelden beklentileri, rakiplerin oda fiyatları, bölgeyi ziyaret eden turist sayıları, bulundukları bölgedeki tesislerin ortalama geceleme sayıları, rakiplerin sayıs1, rakiplerin farklı sezonlardaki fiyatlama politikaları, turizm yasalarında yapılan düzenlemeler, rakiplerin güçlü ile zayıf yönleri ve rakiplerin doluluk oranlarıdır. Wang, Chen ve Chen (2012), gerçekleştirdikleri çalışmada dış çevre faktörlerinin sürekli değiştiğini bulmuştur. Bu nedenle turizm işletmeleri bakımından dış çevre faktörlerinin analizinin rakiplerin hareketlerini anlama yeteneği kazanma; ürünleri, hizmetleri ve süreçleri geliştirme; rakiplerin eylemlerine verilecek tepkileri geliştirme, e-posta, web siteleri ve sanal topluluklar gibi yeni teknolojileri kullanarak en karlı müşterileri izleyebilme ve bir iş stratejisi olarak pazara uyum sağlamanın hayati öneme sahip olduğu sonucuna ulaşmışlardır. Indris, S. ve Primiana, I. (2015), yaptıkları incelemede iç ve dış çevre analizinin Endonezya'daki KOBI'lerin performansı üzerindeki etkisini bulmayı amaçlamış ve KOBI'ler üzerinde iç ile dış çevre faktörlerinin önemli bir etkisi olduğu ve KOBİ'lerin başarısının iç ve dış çevre analizi yapılması sonrasında artış gösterdiği sonucunu elde etmişlerdir. Johan, Baga ve Asmara (2018), gerçekleştirdikleri araştırmada XYZ otelinin iç ve dış çevre analizini yapmayı ve rekabet yeteneğini arttırmak için strateji geliştirmeyi amaçlamıştır. Bu otelin temel firsatının iş sürecini kolaylaştıran teknolojinin gelişmesi, oteli bekleyen tehdidin ise benzer otellerin çoğalmasıyla müşterilere birçok seçeneklerin sunulması olduğu sonucuna ulaşmışlar ve bu otel için 10 alternatif strateji geliştirerek otelin stratejik mimarisini oluşturmuşlardır.

Ayvalık; coğrafi konumu, bozulmamış doğası, tarihi yapıları, kültürel kaynaklarının zenginliği ve yaygın olan deniz kum güneşten oluşan kitle turizmine ilişkin altyapısı ile büyük bir turizm potansiyelini barındırmaktadır. T. C. Kültür ve Turizm Bakanlığı'nın 2017 istatistiklerine göre, Ayvalık'taki işletme ve belediye belgeli tesislere giriş yapmış yerli ve yabancı toplam turist sayısı 340.142, yapılan geceleme 694.649 ve turizm işletme belgeli konaklama tesisi sayısı ise 22'dir. Ayvalık'ın Balıkesir'de öne çıkan diğer turizm destinasyonlarıyla (Edremit, Burhaniye, vs.) kıyaslandığında pazar payı daha yüksektir ve Balıkesir'de gerçekleşen turizmden aldığ $1 \% 28$ civarındaki pay ile Balıkesir'de en çok turist çeken destinasyondur. Fakat buna karşın 2017 yılında Bodrum'daki turizm işletme ve belediye belgeli tesislere gelmiş yerli ve yabancı toplam turist sayısı 1.182.808, yapılan toplam geceleme 3.930.854 ve turizm işletme belgeli konaklama tesisi sayısı ise 165 'tir. Marmaris'teki turizm işletme ve belediye belgeli tesislere gelmiş yerli ve yabancı toplam turist sayıs 1.257.305, yapılan toplam geceleme 4.260.991 ve turizm işletme belgeli konaklama tesisi sayısı ise 123'tür 
(http://yigm.kulturturizm.gov.tr). Bu veriler, Ayvalık destinasyonunun rakiplerine göre turizm işletme belgeli tesis sayısının oldukça az olduğunu göstermektedir. Ayvalık, sahip olduğu Türkiye'nin en büyük tabiat parkı, tarihi, doğası, kültürü, mimari yapısı, yemek kültürü, su sporları ve deniz dip yapısının zenginliği, berrak denizi ve sahillerine rağmen Bodrum ve Marmaris gibi Ege bölgesinde bulunan diğer turizm destinasyonlarından daha az turist çekmekte ve turizm pastasından istediği payı alamamaktadır. Ayvalık, Bodrum ve Marmaris gibi turizmde payı daha yüksek olan destinasyonlarla kendini kıyaslaması gerekmektedir. Turizm ürünlerinin rekabet yeteneği; ciddi ölçüde genel coğrafik destinasyonun imaj, organizasyon, kalite ve sürdürülebilirliğine bağlıdır. Bu noktadan hareketle, Ayvalık'ın Ege bölgesindeki diğer turizm destinasyonlarına oranla sahip olduğu turizm potansiyeli, turizm pazarının yapısı, turizm sektöründeki olası rekabet durumu ve dolayısıyla turizm sektörünün firsat ile tehditlerini ortaya koyarak bölgeye turizm alanında katkı sağlamak ve bölge turizmini istenilen seviyelere ulaştırmak için bölgenin turizme ilişkin dış çevre analizi yapılmıştır. Turistik çekicilikleri olan bir destinasyonda turizmin gelişmesi ve stratejik olarak yönetilebilmesi için öncelikle geleceğe yönelik planlama yapılarak o destinasyonun sahip olduğu özelliklerin belirlenmesi gerekir. Destinasyonun güçlü ve zayıf yönleri ortaya çıarılmalıdır. Bundan sonra ise güçlü olan yönler ön plana çıkarılmalı zayıf yönlerin ise nasıl güçlü hale getirileceği tespit edilmelidir. Araştırma kapsamında elde edinilen sonuçlar kamuoyu ile paylaşılarak bölge turizmi için gelecekte oluşturulabilecek stratejik turizm planına yönelik önerilerde bulunulması planlanmaktadır. $\mathrm{Bu}$ bağlamda, çalışmanın literatür kısmında dış çevre analizi ve destinasyon ile dış çevre ilişkisi konuları incelenmiştir.

\section{Dış Çevre Analizi}

Çalışmanın bu bölümünde incelenen alanla ilgili yazın taranarak stratejik yönetimde dış çevre kavramı ve bir sonraki bölümde ise destinasyon ve dış çevre ilişkisi ile ilgili açıklamalar yapılmıştır.

Çevre analizi, uzak / genel çevre analizinden ve yakın / sektör çevresinin analizinden oluşan dış çevre ile işletme içi analizinden oluşan iç çevreden oluşmaktadır (Ülgen ve Mirze, 2018, s. 67). Dış çevre, işletmenin genellikle kısa vadede değiştiremediği büyük olay ve durumlardır. İşletmenin içinde bulunduğu ekonomik sistem, ekonomik göstergeler, teknoloji kullanım düzeyi, politik ve hukuki çevre, demografi ve uluslararası çevre işletmeleri kuşatmıştır (Babacan vd., 2017, s. 54).

Dış çevre, yakın ile uzak çevre şeklinde ikiye ayrılmaktadır. Politik çevre, yasal çevre, ekonomik çevre, sosyokültürel çevre, demografik çevre, teknolojik çevre ve uluslararası çevre uzak çevreyi meydana getirmekte; tedarikçiler, rakipler, müşteriler ve ikame mal ile hizmetler ise yakın çevreyi oluşturmaktadır (Güripek, 2013, s. 21).

Dış çevre analizinde genel çevre ya da uzak çevre unsurları ekonomik, sosyokültürel, küresel, teknolojik, demografik, ekolojik ve politik/yasal olmak üzere yediye ayrılmaktadır. Ekonomik faktörler; kriz dönemleri, destekler, arz talep, cari açık, dış ticaret işlemleri, makro ekonomik politikalar, alım gücü, istihdam, rakipler, müşterilerden oluşmaktadır (Canbaz, 2014, s. 44). En önemli ekonomik faktörler; büyüme hızı, faiz oranları, döviz kurları ve enflasyon (ya da deflâsyon) olmak üzere dörde ayrılmaktadır (Yılmaz, 2012, s. 46). Milli gelirin yapısı, ekonomik büyüme ve yatırımlar, enflasyonist ve deflasyonist eğilimler, ekonominin gelişim devresi, diş ticaret ve ödemeler dengesi diğer ekonomik faktörlerdir (Babacan vd., 2017, s. 55). Politik (siyasal) ve hukuki faktörlerin; hükümetlerin hukuki düzenlemeleri, teşvikleri, merkezi veya yerel seçimler, merkezi ve yerel yönetim, uluslararası anlaşmalardan oluştuğunu söyleyebiliriz. Yasal çevre, politik çevrede bulunan unsurların işletmelere olan etkisi yani bir ülkede veya bölgede yönetenlerin yaptıkları yasalar, yönetmelikler ve kararlarla oluşmaktadır. $\mathrm{Bu}$ yüzden yasal çevre unsurlarını politik çevre unsurlarının somut kurallara çevrilmiş biçimi şeklinde tanımlayabiliriz (Fettahlıŏlu vd., 2016, s. 750). Ticaret, borçlar, eşya, icra ve iflas, vergi, iş hukukları, hukuki çevreyi oluştururlar. Sosyokültürel faktörler; toplumsal faktörler, 
demografik veriler, gelenek görenek, kültür, moda, yaşam tarzı, yoksulluk ve zenginlik gibi unsurlardır (Canbaz, 2014, s. 44). Farklı kültürlere sahip olan milliyetler için değişik kültür turları düzenlenmesi ile konaklama tesislerinin hitap ettikleri hedef kitleye göre uygulayacakları konseptleri belirlemeleri, bu faktöre örnek verilebilir. Teknolojik faktörler; yeni bilgilerin yaratıldığ 1 ve farklı ortamlarda ürün ve süreçlere gelişim sağlayan faaliyetlerdir (Babacan vd., 2017, s. 55). İletişim ve bilgi teknolojileri, internet, cep telefonu, bilgisayar, iş ve sosyal hayattaki teknolojik aletlerdir (Canbaz, 2014, s. 44). Günümüzdeki en önemli teknolojik değişimler; taşıma teknolojilerinin hızlanması, geliş̧miş iletişim teknolojisi ile sosyal ilişkide zaman kavramının öneminin azalması, sanal gerçeklik ile deney, öğrenme ve eğlenmenin aynı anda duyarak ve görerek yapılabilmesi, yapay zekanın günden güne gelişmesidir. Demografik faktörler; işletmelerin faaliyet gösterdiği bölgedeki nüfus yapısı, o nüfusun özellikleri ve tercihlerine ilişkin unsurları içerir. Buna ek olarak nüfus yapısının sayısal büyüklügü̈, yaş grupları, kadın- erkek oranı, etnik yapı, nüfusun dağılımı, gelir ve eğitim durumları gibi unsurları da içerir. Demografik faktörlerdeki değişikliğin ortaya çıkaracağı firsat ve tehditler, toplumsal hayatın geleceğini yani işletmelerin gelecekte olmaları gereken konumlarını etkiler (Yılmaz, 2012, s. 49). Küresel faktörler; küresel güçler ya da uluslararası çevre, işletmenin faaliyet gösterdiği ülkeden başka yabancı ülkelerdeki olanakları ve tehlikeleri kapsayan politik, yasal, ekonomik ve sektörle ilgili olayları ve oyuncuları (müşteriler, tedarikçiler, rakipler) kapsar (Yılmaz, 2012, s. 47). Örneğin Avrupa'da herhangi bir ekonomik kriz meydana gelme beklentisi oluşması, Türkiye'deki işletmelerin bu krize karşı ne gibi önlemler alması gerektiği tahmininde bulunmalarına neden olmaktadır. Ekolojik (doğal) faktörler; deprem, sel, yangın, çevre kirliliği, tsunami, su kirliliği, buzların erimesi olabilir (Canbaz, 2014, s. 44). Bunların yanı sıra iklim değişiklikleri, arazinin yapısı ile turizm faaliyetini etkileyen bir şehrin sahip olduğu doğal güzellikler bu faktörler içerisinde yer alırlar.

İşletmenin yakın ya da iş çevresi, işletmenin girdilerini sağladığı tedarikçilerinin, işletmede üretilen mal ve hizmetlerini sattığ müşterilerinin ve benzer, tamamlayıcı veya yerine geçebilecek mal ve hizmetleri üreterek satan rakiplerinin olduğu, işletmenin faaliyetlerine direk olarak etki eden çevredir. Yakın / iş çevresi analizi, 3 ana başlıkta toplanmaktadır: ana pazarın incelenmesi, rekabet analizi ve rakip firma analizidir (Ülgen ve Mirze, 2018, s. 106). Yakın çevre analiz süreci, Şekil 1'de gösterilmiştir.

Şekil 1. Yakın çevre analiz süreci

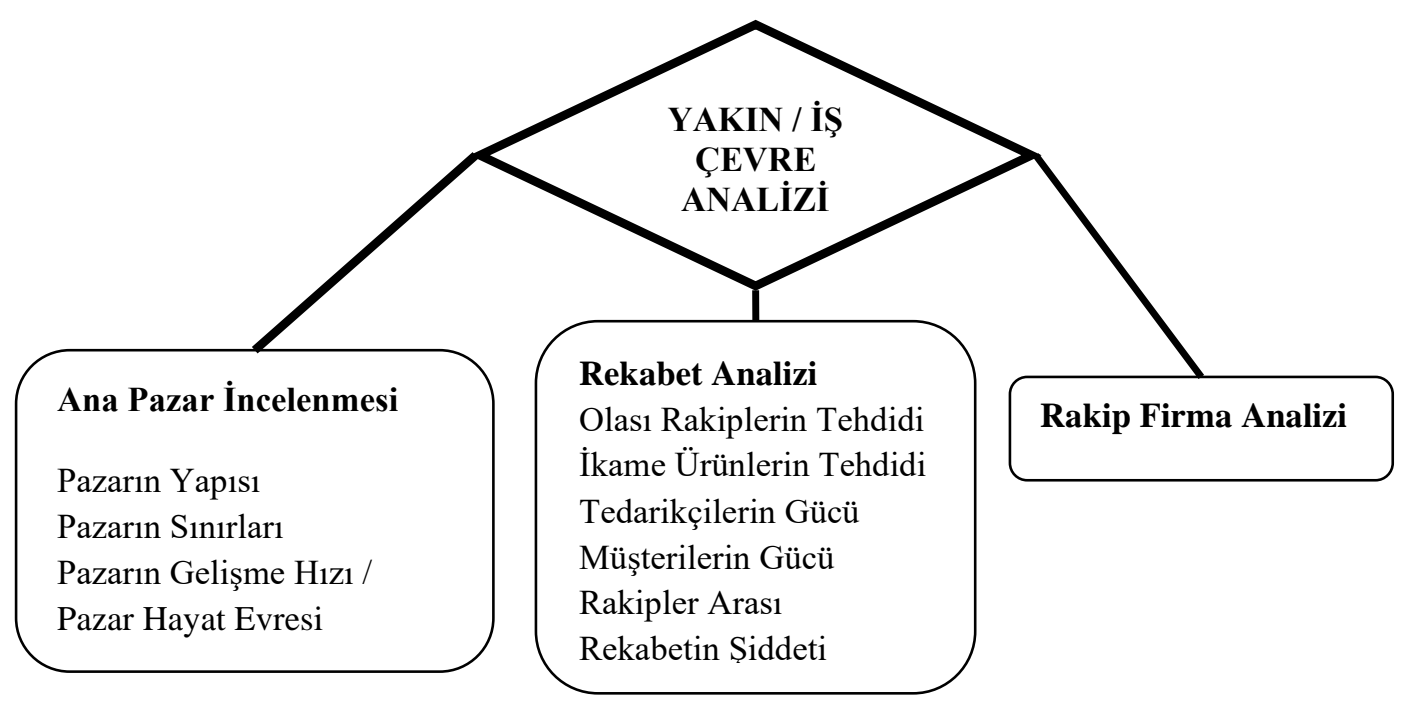

Kaynak: Ülgen ve Mirze, 2018, s. 107 
Ana Pazar; işletmenin mal ve hizmetlerini satışa sunduğu, rakip işletmelerle rekabet halinde olduğu ve bu faaliyetleri neticesinde kazanç sağlamayı beklediği pazardır (Sucu, 2010, s. 84). Ana pazarın analizi; pazarın yapısı, pazarın sınırlarının belirlenmesi ve pazarın gelişim hızı veya pazar yaşam döngüsü dikkate alınarak yapılmaktadır. Pazar yapısını belirleyen özellikler; o pazarda faaliyet gösteren işletmelerin sayısı, pazardaki rekabet seviyesi (monopol, oligopol, tam rekabet pazarı) ve pazara giriş zorluk derecesidir (Ülgen ve Mirze, 2018, s. 109). Pazarın sınırları belirlenirken coğrafi ve bölgesel konumun dikkate alınması gerekmektedir. Pazarın gelişme hızı belirlenirken ise işletme bakımından pazarın olumlu ya da olumsuz gelişim düzeyi belirlenmek için çaba sarf edilir. Sektör ortamının analiz edilmesi, işletmenin sektörde iyi bir konum elde edebilmesi ve doğru bir stratejiye karar verebilmesi için gerekli bir ön şarttır (Kayabaşı, 2017, s. 23).

İletişim teknolojilerinin gelişmesi sonrasında global rekabetin artması, işletmeleri bir yandan rakiplerinin hamlelerini ve değişimlerini algılayabilmek için gayret göstermeye diğer taraftan da alıcıların ve mal sağlayan firmaların pazarlıkta sahip olduğu güçlerini belirlemesini gerekli kılmıştır. Porter, işletmelerin yakın çevresindeki rekabeti ortaya çıkaran unsurları 5 başlikta toplamıştır (Sucu, 2010, s. 87). Söz konusu 5 güç şunlardır: pazara girenlerin tehdidi, rekabetin şiddeti, ikame ürünlerin tehdidi, müşterilerin pazarlık gücü ve tedarikçilerin pazarlık gücüdür (Mathooko ve Ogutu, 2015, s. 337). Bir pazarda potansiyel ile var olan rakiplerin ikisi de sektörel ortalama karlılığ 1 etkiler ve diğer rakipleri için tehdit oluştururlar. Pazara yeni girenlerin yarattığ 1 tehlikeyi analiz etmede temel kavram, giriş zorluklarıdır. Bu zorluklar, farklı şekillerde olabilirler ve firmaların bir sektöre girişini engellerler (Karagiannopoulos vd., 2005, s. 69). Pazardaki bir ürün veya hizmet için tehdit unsuru olan ikame ürün, orijinal ürüne kıyasla ucuz maliyetli bir alışveriş sağlarsa ikame ürünlerin tehdidi yüksek olur (Mathooko ve Ogutu, 2015, s. 337). Turizm sektöründe, ikame ürünlerin tehdidinden daha çok yurtiçi seyahatlerin, yurt dışı seyahatlerle değiştirilmesi ya da bazı destinasyonların maliyetler gerekçesiyle daha uygun maliyetlere sahip destinasyonlarla değiştirilmesi gibi sorunlar olarak karşılaşılmaktadır. Aynı şekilde hedef kitleyi oluşturan bazı turistlerin daha ucuz motel, pansiyon gibi işletmelerde kalma yönünde eğilimleri ortaya çıkabilmektedir. Çünkü turizm sektörü, fiyatlara oldukça duyarlı bir pazardan oluşmaktadır (Göral, 2014, s. 79). Müsşteriler, pazardaki rekabeti olumlu ya da olumsuz yönde etkileyebilirler. Müssterilerin; daha kaliteli ürün ve hizmet gibi maliyetleri arttıran beklentilere sahip olmaları ile fiyatların daha düşük olmasına yönelik pazarlık gücünü elinde bulundurmaları, rekabet açısından bir tehdit gibi görünse de pazarlık gücü az olan müşteriler, işletmelerin fiyatlarını arttırarak daha çok kazanç olanağı sağlarlar (Sucu, 2010, s. 89). Tedarikçilerin gücü ise öncelikle sektörel katılımcılarla ilgili olarak tedarikçilerin nispi büyüklük ile yoğunluğuna ve ikinci olarak ise sağlanan girdilerdeki farklılaşma derecesine odaklanır (Karagiannopoulos v.d., 2005, s. 69). Son olarak; rakipler arasındaki pazarlama ve reklam faaliyetleri, işletmelerin fiyatlamada izlediği yollar, sürekli rakipten daha fazla üstünlük sağlamak amacıyla piyasaya yeni ürün arz edilmesi, müşteri hizmetlerinin önem kazanması gibi sebepler rakipler arasındaki rekabetin şiddetini belirleyen başlıca faktörlerdir (Sucu, 2010, s. 89).

Rakip firma analizinde ise esas rakip (veya rakipler), işletmenin karar ve eylemlerinde dikkate alması gereken en önemli etkendir. Bu yüzden esas rakip ve rakiplerin yakın dış çevre analizinde ayrı bir şekilde incelenmesi ve analiz edilmesi, stratejik yönetimin en önemli safhalarından biridir (Ülgen ve Mirze, 2018, s. 116). Rakip firma analizinde rakibin gelecekteki hedefleri, ortaya çıkardığı varsayımlar, uygulamakta olduğu stratejileri ve elinde bulundurduğu beceriler ele alınarak incelenir. Bu inceleme sonucunda işletmenin izlemesi gereken stratejiler tekrar gözden geçirilerek yeniden belirlenir.

\section{Destinasyon ve Dış Çevre İlişskisi}

Destinasyonla ilgili yapılan farklı tanımlar bulunmaktadır. Turistik destinasyon teriminin literatürde sık kullanılması, herkes tarafından kabul görmüş bir tanıma ve içeriğe sahip olduğunu göstermez (Martini vd., 2003, s. 1). Turizmde destinasyon; turistik istasyon, turizm 
destinasyonu, turistik destinasyon, turizm bölgesi olarak adlandırılmaktadır. Fakat bu ifadelerin hepsinde tatilde yaşananların gerçekleştiği yöre anlatılmaktadır. Genel olarak destinasyon, doğal, tarihi ve kültürel çekicilikler ile turistik zenginlikleri barındıran ve bu yüzden turistin kazanç elde etme ve sürekli yaşama düşüncesi olmaksızın ciddi manada ziyarette bulundukları coğrafi bir yöredir (İlban, 2007, s. 5). Buhalis'e göre turistik destinasyon; karışık turistik ürün ve hizmetlerle ziyaretçilere bütünleştirilmiş bir deneyim yaşatan ülke veya kent gibi tanımı iyi yapılmış coğrafi alandır (Buhalis, 2000, s. 97). Bir başka tanıma göre bir turizm destinasyonu, bünyesinde barındırdığ 1 farklı turizm zenginlikleri ile turistler için çekiciliğe sahip ve sürekli şekilde ziyaretçileri ağırlayan pek çok paydaşın sunduğu direk veya dolaylı turizm hareketlerinin birleşiminden meydana gelen bir üründür (Özdemir, 2007, s. 1). Özetle bir bölgenin destinasyon olması için doğal, tarihi ve kültürel çekicilere, o şehre bölgeye gelenleri ağırlayacak konaklama tesisleri, restoranlar, eğlenmeleri ile vakit geçirmeleri için de gezilecek görülecek yerler ve eğlence mekanlarına sahip olması gerekmektedir.

Turizm işletmelerinin uluslararası rekabet yeteneği ne ülkeler veya bölgeler ne de ulusal veya bölgesel endüstriler olarak düşünülmez ama onun yerine belli stratejik bölümlere ayrılmış destinasyonlar olarak düşünülür. $\mathrm{Bu}$ bakış açısı, sektöre göre gruplamaya odaklanmasıyla turizm işletmelerin bulunduğu turistik destinasyonun etkisini analiz etmenin önemini vurgulamaktadır (Camison ve Fores, 2015, s. 480). Destinasyonların etkili olarak yönlendirilmesi ve pazarlanması amacıyla o bölgeyi meydana getiren faktörlerin ve niteliklerin, ayrıntılı bir şekilde incelenip değerlendirilmesi ve gerekli analizlerin uygulanarak en uygun stratejilerin izlenmesi gerekmektedir (Bardakoğlu, 2011, s. 30). Turistik destinasyonların doğaya ve kültüre ilişkin kaynaklarını kapsayan ve çok sayıda sektörün birleşmesiyle meydana gelen çok yönlü bir yap1 olmas1, planlama sürecinde sistemli bir yaklaşımı zorunlu hale getirmektedir (Hassan, 2000, s. 75). Stratejik destinasyon yönetiminin bir aşaması olan dış çevre analizinde, destinasyonu planlanan hedefleri gerçekleşmesini sağlayacak kaynaklar (ekonomik, personel, idari, vb.) ve çekicilikler gibi olanakların bulunup bulunmadığı tespit edilmelidir (Güripek, 2013, s. 66).

Turistik destinasyonu yönetenler, başka bölgelerin taklidini yapmak yerine; o bölge için rekabet avantajı olabilecek turizm ürünlerini tespit ederek bunları öne çıkartmayı, destinasyonun stratejik yönetimiyle sağlayabilirler. Başka bir deyişle destinasyonun stratejik olarak yönetilmesi için o destinasyonu oluşturan unsurların kendi aralarında uyumlu olması gerekmektedir. Örneğin, bir destinasyonda güzel manzaraya sahip bir seyir tepesi olabilir fakat bu doğal kaynağın olması, bu tepeye ulaşımın sağlanmasını ve burada çeşitli yiyecek-içecek hizmeti sunan tesislerin yapılmasını gerektirmektedir.

Bir destinasyondaki firmaların rekabetçi pozisyonunda en büyük etkiyi yapan diş çevre faktörlerinden biri, bulundukları bölgede sahip olunan varlıkların gelir sağlama durumudur (Camison ve Fores, 2015, s. 479). Turistik çekicilikleri olan bir yörede turizmin gelişmesi ve stratejik olarak yönetilebilmesi için öncelikle geleceğe yönelik planlama yapılarak o destinasyonun sahip olduğu özelliklerin belirlenmesi gerekir. Destinasyonun güçlü ve zayıf yönleri ortaya çıkarılmalıdır. Bundan sonra ise güçlü olan yönler ön plana çıkarılmalı zayıf yönlerin ise nasıl güçlü hale getirileceği tespit edilmelidir. Turizmde rekabet kavramı, küreselleşmenin de etkisiyle firmalar arası rekabetten destinasyonlar arası rekabet şeklinde değişiklik göstermiştir. Yani bir destinasyonun rekabet gücü, o destinasyondaki işletmelerin ne kadar birlikte hareket ettiklerine bağlıdır.

Turizm ürünü; bir bütündür, karışımdır, somut ve soyut unsurlardan oluşur. Turizm işletmelerinin rekabet yeteneği ve işletmenin bulunduğu turizm destinasyonunun genel rekabet yeteneği arasındaki ilişki, turizm ürününün bütünleştirilmiş bir ürün olmasıyla açıklanabilir. $\mathrm{Bu}$ noktadan hareketle bir destinasyondaki turizm işletmelerinin rekabet yeteneği; 0 destinasyondaki tüm işletmeler tarafından sunulan ulaşım, konaklama, restoranlar vb. gibi tamamlayıcı aktiviteler ve ürünlerin, turistlerin karar verirken en çok değer verdikleri özellikleri ne dereceye kadar içerdiğine bağlıdır (Camison ve Fores, 2015, s. 480). Örneğin tatilde sadece 
kalınan otel değil aynı zamanda o otelin bulunduğu destinasyonun tarihi, kültürü, yemekleri, oradaki insanların yaşam tarzı ve davranışları da turistleri etkiler. Çünkü turistlerin konakladıkları tesisten dışarı çıktıklarında yaşadığı her deneyim, onlarda olumlu veya olumsuz bir iz bırakır. Bu izler, onların bir sonraki tatil kararını vermelerinde etkili olurlar. Destinasyon rekabetçiliği ise destinasyonların, rakiplerine göre pozisyonlarını korumaları, sahip olduğu zenginliklerle değer yaratan ürünler üretme ve bu ürünleri birleştirme becerisi olarak tanımlanmaktadır (Hassan, 2000, s. 240). Ayvalık'taki deniz suyunun güneydeki turistik destinasyonlara ( Bodrum, Marmaris, vs. ) göre daha serin olması, ilçenin daha bakir alanlara sahip olması (yaz sezonunda bile aşırı turist yoğunluğunun yaşanmaması), insanların dinlenmesi için çok sayıda sessiz ve sakin noktaların bulunması, Ayvalık Adaları Tabiat Parkı ile eşsiz bir doğaya sahip olması (Türkiye'nin en büyük tabiat parkı) gibi özellikler Ayvalık'ı rakiplerinden farklı kılan ve rekabet avantajına sahip olmasını sağlayan faktörlerdir.

\section{Yöntem}

$\mathrm{Bu}$ araştırmanın amacı, bölgede faaliyet gösteren konaklama işletmeleri açısından Ayvalık destinasyonunun dış çevre analizinin yapılmasıdır. Ayvalık turizm sektörü verilerinin incelenmesiyle birlikte turizm pazarının yapısı, sınırları ve pazarın gelişme hızı belirlenmiştir. Buna ek olarak rekabet analizi ile rakip analizleri yapılmıştır. Buradan hareketle elde edilen bulgular analiz edilerek bölgedeki turizm işletmeleri ile yerel paydaşlara ve ayrıca bölge turizmi için gelecekte oluşturulabilecek stratejik turizm planına yönelik önerilerde bulunulmuştur.

Bu çalışma, Ayvalık turizm sektörünün dış çevresi dolayısıyla pazarın genel durumu hakkında fikir vermekte ve alan yazın taramasında çok fazla rastlanılmayan dış çevre analizi konusunda yapıldığından gelecek çalışmalara referans oluşturacak nitelikte orijinal ve özgün bir yapıya sahiptir. Buna ek olarak Ayvalık'ta gelecek yıllarda turizm sektöründe yatırım yapmayı planlayan girişimcilere turizm sektörünün mevcut durumu ile ilgili bilgiler sağlayıp rehberlik edeceğinden ve sağladığı güncel verilerle yatırımcıların yatırım kararı vermelerinde yol gösterici nitelikte olduğundan büyük bir öneme sahiptir.

$\mathrm{Bu}$ çalışma, nitel bir araştırma özelliği taşımaktadır. Araştırmada, nitel araştırma yöntemlerinden içerik analiz yöntemi kullanılmıştır. Nitel araştırma, belli bir noktada odaklanmada çok metotlu; araştırma problemine yorumlayıcı gözle bakmayı benimseyen bir yöntemdir. Bu yöntemde araştırmacılar, araştırmaya konu olan olayları, doğal ortamında ele alırlar. Olaylar, araştırmacının ona yüklediği anlama göre yorumlanırlar (Coşkun vd., 2015, s. 303).

Araştırmada, vakanın analiz edilebilmesi için ikincil veri kaynaklarından veri toplama yöntemlerinden yararlanılmıştır. Vaka analizi, güncel bir konuyu gerçek hayatın içinde çalışan ve durumları farkl1 yönlerden, sistemli ve derin bir şekilde ele alan görgül bir araştırma metodudur (Önen, 2017, s. 373). Araştırmada, ikincil veri kaynaklarından özellikle Ayvalık Turizm Danışma Bürosu ile Kurumun resmi internet sitesinden sağlanan bölgenin turizm hacmini ve potansiyelini gösteren veriler, T.C. Kültür ve Turizm Bakanlığının Ayvalık turizmine ilişkin istatistiki verileri, Ayvalık Belediye Başkanlığından sağlanan veriler, T.C. Tarım ve Orman Bakanlığı Doğa Koruma ve Milli Parklar Genel Müdürlüğü, Ayvalık Adaları Tabiat Parkı resmi internet sitesinden bölgenin doğal çevresine ilişkin temin edilen veriler, bölgede faaliyet gösteren turizm işletmeleri ile gerçekleştirilen görüşmelerden elde edilen veriler ve incelenen konuya ilişkin yapılan Türkçe ve yabancı alan yazın taramasında ulaşılan bilgiler kullanılmıştır. Çalışma, ana faaliyet konusu olan Ayvalık destinasyonu kapsamında sınırlandırılmıştır.

\section{Bulgular}

Araştırma bulguları, 2 bölümden oluşmaktadır. Birinci bölümde Ayvalık destinasyonunun uzak çevre analizi gerçekleştirilmiştir. İkinci bölümde yakın / iş çevre analizi kapsamında turizm pazar yapısı incelenmiş, rekabet ve rakip analizleri yapılmıştır. 


\subsection{Uzak Çevre Analizi}

$\mathrm{Bu}$ bölümde Ayvalık destinasyonunun turizme ilişkin dış çevresi ekonomik, sosyokültürel, politik-siyasal ve doğal çevre boyutlarıyla incelenmiş ve elde edilen bulgular Tablo 1'de verilmiştir.

Tablo 1. Ayvalık turizm pazarı uzak çevresi

\section{Ekonomik Cevre}

- Ayvalık'ı yıllık 500-600 bin yerli ve yabancı turist ziyaret etmektedir.

- 2018'de Ayvalık'ta konaklama tesislerindeki gecelemelerde geçen yıla göre \%19 artış olmuştur.

- Sezonluk fiyat artışı ve fiyatlandırmadaki değişiklikler; arz ve talep modelini değişstirmekte, konaklama tesislerine gelen müşteri profilinin alım gücünü etkilemekte ve tatil, lüks bir ihtiyaç haline gelmektedir. Riski hisseden tüketiciler, öncelikli olarak tatilden vazgeçebilmektedirler.

\section{Sosyokültürrel Çevre}

- Yerel halk, Türkiye'nin farklı yerlerinden göç etmiş vatandaşlarımız, Midilli ve Girit mübadilleri ile Boşnak vatandaşlarımızdan oluşmaktadır.

- Tabiat Parkındaki zeytinlik bölgeler, geleneksel tarzla şekillenen özgün dokusu ve tarihi yapılarıyla yörenin kültürel açıdan peyzaj zenginliğini ortaya koymaktadır.

- Destinasyonun hitap ettiği hedef kitle, \%20 yabancı turist geldiğinden öncelikle iç pazardır.

\section{Politik - Siyasal Çevre}

- “Ayvalık Endüstriyel Peyzajı” olarak "UNESCO Dünya Mirası Geçici Listesi"nde yer almaktadır.

- Ayvalık, "Kültür ve Turizm Koruma ve Gelişism Bölgesi” ilan edilmemiştir. Yani bölgeye yeni yatırım yapmak isteyen girişimciler, bazı devlet teşviklerinden faydalanamayabilirler.

- Bölgede çok sayıda ev pansiyonu mevcuttur.

- Ayvalık; tarihi dokusu, doğal çevre zenginliğiyle Ege kıyısının en güzel yerleşimlerindendir.
- Türkiye'nin en uzun sahillerinden biri olan Sarımsaklı plajına sahiptir.
- Bölgede 1.910.485 adet zeytin ağacı bulunmaktadır (yaklaşık \%95'i mahsul vermektedir).
- Ayvalık'ta 17'si Anadolu'ya özgü, 4'ü endemik 750 bitki türü saptanmıştır.
- Doğa ve sualtı zenginlikleriyle, 1995'ten itibaren Tabiat Parkı ilanıyla koruma altındadır
- Bahar ve yaz aylarında, Tuzla Gölü'ndeki flamingolar, doğaseverler için görülmeye değerdir.
- Ayvalık, 34 noktada Kırmızı Mercan tespitiyle Kızıldeniz'den üstündür.
- Kaz Dağları ve Kozak Yaylası gibi alanlarda maden aramaları, HES Projeleri gibi doğal yaşama
zarar veren uygulamalar tehdit oluşturmaktadır.
- Bölgenin alt yapı sorunları, turizmi olumsuz etkilemektedir.

Kaynak: Kültür ve Turizm Bakanlığı, Ayvalık Turizm Danışma Bürosu, Doğa Koruma ve Milli Parklar Genel Müdürlüğü, UNESCO ile UZZK web sitelerinden ve bölgedeki turizm işletmeleri ile yapılan görüşmelerden derlenmiştir.

Tablo 1 incelendiğinde Ayvalık'ta 2018 yllında konaklama tesislerindeki geceleme sayılarına göre turizm hareketliliğinin arttığı; destinasyona gelen yabancı turist oranı yaklaşık $\% 20$ olduğundan, hedef kitlenin ağırlıklı iç pazardan oluştuğu; destinasyonunun eşsiz su altı ile doğal güzellikleri ve Türkiye'nin en büyük Doğa ve Tabiat Parkı olan Ayvalık Adaları Tabiat Parkına sahip olduğu; "Ayvalık Endüstriyel Peyzajı” olarak "UNESCO Dünya Mirası Geçici 
Listesi"nde yer almasıyla diğer destinasyonlardan kültürel olarak farklılığını ortaya koyduğu; dalış turizminin yapıldığı bölgede 34 noktada kırmızı mercan tespit edildiği; bölgede bulunan flamingoların yanı sıra endemik bitkilerin olmasının da doğaseverlerin ilgisini çekebilecek bir özelliğe sahip olduğu görülmektedir. Tüm bu olumlu özelliklerin yanında Kaz Dağları ve Kozak Yaylası gibi alanlarda maden aramaları, HES Projeleri gibi uygulamaların tehdit oluşturduğu ifade edilebilir.

\subsection{Yakın Çevre Analizi}

$\mathrm{Bu}$ bölümde Ayvalık destinasyonu turizme ilişkin yakın çevre analizine tabi tutulmuştur. Bu kapsamda Ayvalık turizm pazarı incelenmiş, turizm pazarının rekabet analizi ve rakip analizi yapılmıştır. Ayvalık turizm pazarının incelenmesi ve analizi sonucunda ortaya çıkarılan bulgular, Tablo 2'de verilmiştir.

Tablo 2. Ayvalık turizm pazarının incelenmesi

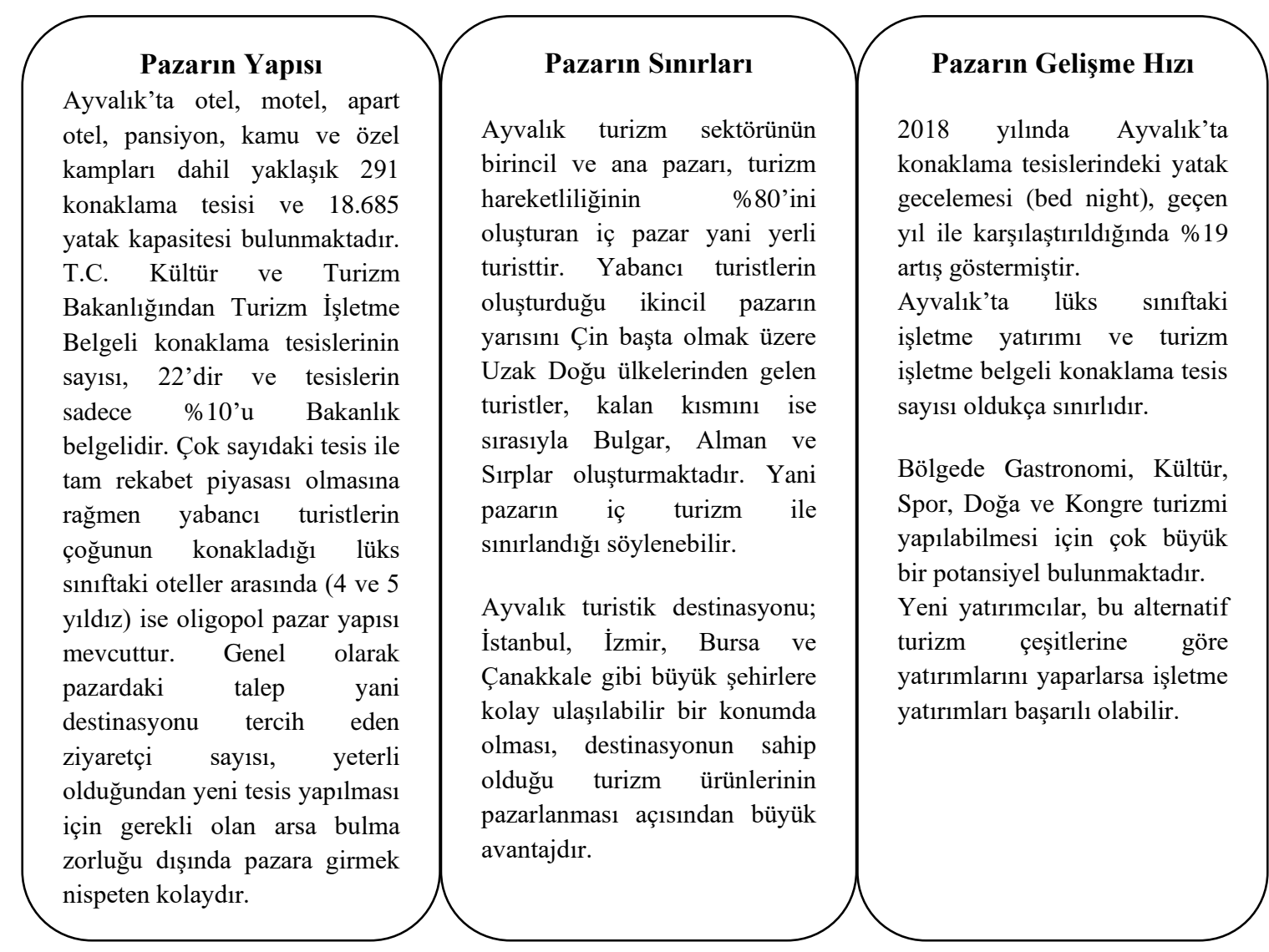

Kaynak: Konaklama tesislerinde yapılan geceleme verileri, Kültür ve Turizm Bakanlığından ve milliyet dağılımı ise Ayvalık Turizm Danışma Bürosundan temin edilmiş ve bölgede turizm işletmeleri ile yapılan görüşmeler yorumlanarak tabloya dönüştürülmüştür.

Tablo 2. incelendiğinde Ayvalık'ta hizmete sunulan konaklama tesisi sayısının 291, yatak kapasitenin ise yaklaşı 18.685 olduğu; turizm pazarının \% 80'ini oluşturan yerli turistlerin birincil pazarı oluşturduğu, yarısından fazlası uzak doğu pazarından oluşan yabancı turistlerin ise ikincil pazarı oluşturduğu; pazar genelinde tesis sayısı fazla olması sebebiyle tam rekabet piyasa koşulları hakim iken az sayıdaki lüks sınıftaki konaklama tesisleri arasında oligopol pazar yapısının ortaya çıktı̆̆ı; İstanbul, İzmir, Bursa ve Çanakkale gibi büyük şehirlere kolay ulaşılabilir bir coğrafi konuma sahip olması destinasyonun hedef kitleye pazarlamasında rekabet avantajı sağladığ1; destinasyonun gastronomi, kültür, spor, doğa ve kongre turizmi 
yapılabilmesi için potansiyele sahip olduğu görülmektedir. Ayvalık turizm pazarı rekabet analizi 5 güç modeli, Şekil 2'de gösterilmiştir.

Şekil 2. Ayvalık turizm pazarı rekabet analizi - 5 güç modeli

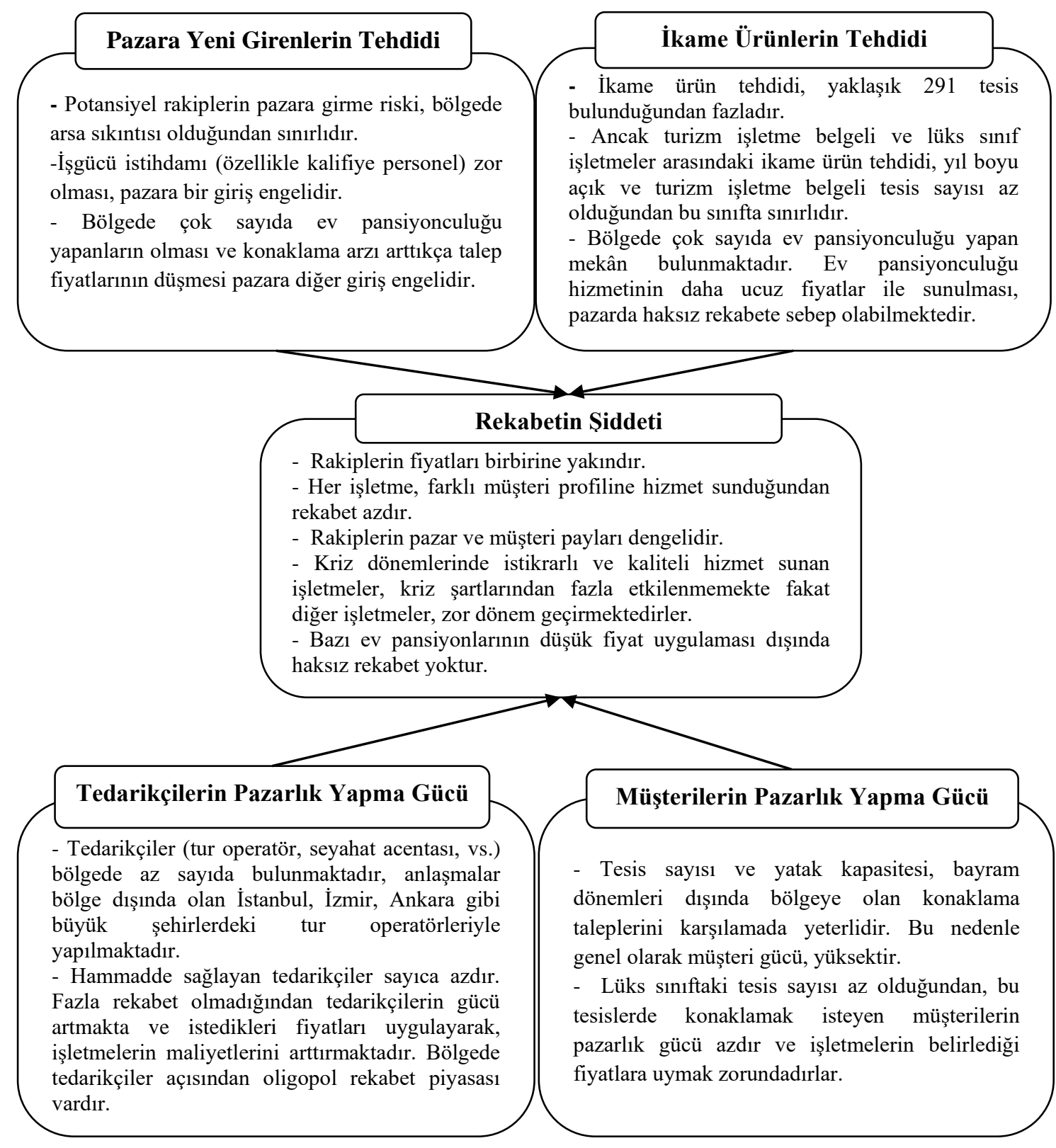

Kaynak: Ayvalık Turizm Danışma Bürosundan alınan Ayvalık turizm sektörüne ait bazı veriler ve bölgede turizm işletmeleri ile yapılan görüşmeler sonucunda bu tablo oluşturulmuştur.

Şekil 2 incelendiğinde bölgedeki arsa sıkıntısı ile kalifiye personel bulma zorluğunun pazara yeni girenler için tehdit oluşturduğu; bölgede konaklama tesisi sayısı çok olduğundan ikame ürün tehdidinin fazla olduğu; turizm işletmelerinin hizmet sunmaları için gerekli ürünleri satın alacakları az sayıda tedarikçi olduğundan tedarikçi gücünün yüksek; konaklama tesis sayısı fazla olduğundan müşteri gücünün yüksek olduğu; farklı konaklama tesis türlerinin farklı nitelikte hizmetleri sunduklarından rekabet oranının düşük olduğu görülmektedir. Ayvalık'ta faaliyet gösteren konaklama tesislerine ilişkin bilgiler Tablo 3'te verilmiştir. 
Tablo 3. Ayvalık turizm pazarı rakip analizi - konaklama tesisleri listesi

\begin{tabular}{ccccc}
\hline No & Tesis Türü & Adet & Oda Sayıs & Yatak Kapasitesi \\
\hline $\mathbf{1}$ & $5^{*}$ & 2 & 500 & 1.024 \\
\hline $\mathbf{2}$ & $4^{*}$ & 3 & 409 & 820 \\
\hline $\mathbf{3}$ & $3^{*}$ & 4 & 222 & 448 \\
\hline $\mathbf{4}$ & $2^{*}$ & 3 & 116 & 236 \\
\hline $\mathbf{5}$ & 8 & 199 & 410 \\
\hline $\mathbf{6}$ & Özel Konaklama Tesisi & 1 & 17 & 36 \\
\hline $\mathbf{7}$ & Butik Otel & 1 & 16 & 32 \\
\hline- & Pansiyon & $\mathbf{2 2}$ & $\mathbf{1 . 4 7 9}$ & $\mathbf{3 . 0 0 6}$ \\
\hline $\mathbf{8}$ & Turizm İşletme Belgeli Toplam & 102 & 3.211 & 7.666 \\
\hline $\mathbf{9}$ & Belediye Belgeli Otel & 20 & 367 & 881 \\
\hline $\mathbf{1 0}$ & Belediye Belgeli Motel & 26 & 475 & 1.823 \\
\hline $\mathbf{1 1}$ & Belediye Belgeli Apart Otel & 109 & 890 & 2.065 \\
\hline $\mathbf{1 2}$ & Belediye Belgeli Pansiyon & 12 & 667 & 3.244 \\
\hline & Belediye Belgeli Kamu ve Özel Kampları & $\mathbf{2 9 1}$ & $\mathbf{7 . 0 8 9}$ & $\mathbf{1 8 . 6 8 5}$ \\
\hline
\end{tabular}

Kaynak: Ayvalık Turizm Danışma Bürosu ve Ayvalık Belediye Başkanlığından konaklama tesislerine ilişkin alınan veriler derlenerek bu tablo hazırlanmıştır.

Tablo 3 incelendiğinde Ayvalık’ta 291 adet konaklama tesisinde 7.089 oda, 18.685 yatak kapasitesi bulunduğu görülmektedir. Bu 291 tesisin; 22 adedi Turizm İşletme Belgeli Konaklama Tesisi, 269 adedi de mahalli belgeli tesislerden oluşmaktadır. Ayvalık'ta turizm işletme belgeli toplam 22 konaklama tesisi; 2'si 5 yıldızlı otel, 3'ü 4 yıldızlı otel, 4 'ü 3 yıldızlı otel, 3'ü 2 yıldizlı otel, 8'i özel konaklama tesisi, 1 butik otel ve 1 adet pansiyondan oluşmaktadır. Ayvalık'taki toplam 18.685 yatak kapasitesinin 3.006'sını turizm işletme belgeli tesisler, 12.435 'ini mahalli belgeli tesisler (otel, motel, apart otel, pansiyon) ve 3.244'ünü ise kamu ile özel kamplar oluşturmaktadır. Turizm işletme belgeli 22 tesisin yarısı kış sezonunda hizmet vermemektedir. Mahalli belgeli tesislerin ise yaklaşı $\% 10-15$ civarı 12 ay boyunca hizmet vermektedir. Konaklama tesislerindeki doluluk oranları, okulların kapalı olduğu 15 Haziran-15 Eylül tarihleri arasındaki yaz sezonunda, ortalama \%90-95 aralığındadır. İlçedeki konaklama tesisleri; yaz sezonunda özellikle Temmuz ve Ağustos ayları ile bayram dönemlerinde en yüksek fiyatlarını, sezon geçişleri olan Mayıs ve Ekim aylarında biraz daha düşük fiyat ve kış sezonunda ise en düşük fiyatlarını uygulayarak faaliyetlerini sürdürmektedirler.

\section{Sonuç ve Öneriler}

$\mathrm{Bu}$ araştırmanın amacı, bölgede faaliyet gösteren konaklama işletmeleri açısından Ayvalık destinasyonunun dış çevre analizinin yapılmasıdır. Ayvalık turizm sektörü verilerinin incelenmesiyle birlikte turizm pazarının yapısı, sınırları ve pazarın gelişme hızı belirlenmiştir. Buna ek olarak rekabet analizi ile rakip analizleri yapılmıştır. Ayvalık'ta turizm işletme ve belediye belgeli toplam 291 konaklama tesisi bulunmaktadır. Ancak bu tesislerin sadece 22'si turizm işletme belgelidir. Bu noktada bölgede turizm işletme belgeli tesis sayısı oldukça azdır. $\mathrm{Bu}$ verilere göre Ayvalık'ın bugüne kadar turizm potansiyelini hedeflediği düzeyde değerlendirememesi, turizm işletme belgeli tesis yatırımı ihtiyacına işaret etmektedir.

Araştırma kapsamında gerçekleştirilen Ayvalık destinasyonu uzak çevre analizi sonucunda geçen yıla göre ilçede konaklama tesislerinde gerçekleşen \% 19'luk geceleme artışıyla bölgeye olan turizm talebinin artma yönünde eğilim gösterdiği; "Ayvalık Endüstriyel Peyzajı" olarak "UNESCO Dünya Mirası Geçici Listesi"nde yer almasıyla bölgeyi diğer destinasyonlardan ayırt edici kültür turizmi potansiyeline sahip olduğu; 34 noktada kırmızı mercan tespit edilen bölgenin dalış turizm merkezlerinden biri olduğu; bölgede bulunan flamingoların yanı sıra endemik bitkilerin olması sebebiyle doğaseverlerin ilgisini çekebilecek bir özelliğe sahip olduğu bulunmuştur. Buna ek olarak çalışmada yapılan Ayvalık destinasyonu 
yakın çevre analizi sonucunda ise Ayvalık'ta 18.685 yatak kapasitesinin bulunduğu; bölgeyi ziyaret eden hedef kitlenin \% 20'lik bölümünün yabancı turistlerden oluştuğundan pazarın iç turizm ile sınırlandırılmış olduğu; yabancı turistlerin oluşturduğu ikincil pazarın yarısından fazlasını Çin başta olmak üzere uzak doğu ülkelerinden gelen turistler, kalan kısmını ise sırasıyla Bulgar, Alman ve Sirpların oluşturduğu; bölgede arsa sıkıntısı ile kalifiye personel bulmanın zor olmasının, pazara girişteki başlıca engeller olduğu; turizm işletme belgeli konaklama tesisleri arasında ikame ürün tehdidinin düşük olması sebebiyle oligopol pazar yapısı varken pazar genelinde ise çok sayıda konaklama tesisi arasında tam rekabet piyasa koşullarının hakim olduğu; az sayıdaki tedarikçi arasında rekabet ortamı oluşmadığından tedarikçilerin gücünün yüksek ve çok sayıda konaklama tesisiyle müşteriler için alternatif şansı çok olduğundan müşteri gücünün yüksek olduğu sonuçları elde edilmiştir.

Uzak ve yakın dış çevre analizlerinde bölgenin zayıf ve eksik yönlerinin olduğu ortaya çıkarılmış, konaklama tesisi sayısı çok gibi görünmesine rağmen yeterli sayıda turizm işletme belgeli konaklama tesisinin olmadığı görülmüştür. Ayrıca turizm işletme belgeli tesislerde ve kaliteli hizmet sunan bazı konaklama tesislerinde yaz sezonunda gecelik fiyatın yaklaşık 700 800-TL civarında ve bayram tatillerinde gecelik fiyatın yaklaşık 1000-TL civarında olması; bu tesisler arasında rekabetin şiddetinin düşük, ikame ürün tehdidinin az ve karlılığın fazla olduğunu göstermektedir. Ortaya çıkarılan bu sebepler, bu bölgeye turizm işletme belgeli bir tesis yatırımı yapmanın cazip olacağını ve verimli sonuçlar getirebileceğini göstermektedir.

Hem alan yazın bilgileri, hem bölgede faaliyet gösteren turizm işletmeleri ile yapılan görüşmeler hem de istatistiki verilere göre Ayvalık'ın alternatif turizm potansiyeline ve gelişime açık bir destinasyon yapısına sahip olduğu söylenebilir. Ayvalık'ın bu konudaki güçlü yanlarına bakarsak; doğal ve tarihi çok fazla turistik kaynağı barındırması, geçmişten bugüne taşıdığ çeşitli kültürlerin eşsiz bir harmanı olan mutfağıyla gastronomi turizmi potansiyeli, Ayvalık Adaları Tabiat Parkının doğa turizmine yönelik kullanma imkanı, ünlü zeytin ve zeytinyağıyla zeytinyağı turizmi için gerekli tüm koşullara sahip olması, henüz turizme kazandırılmamış termal su kaynaklarının olması, Tuzla Gölü ve çevresindeki flamingolar ile kuş gözlemciliğini sunabilme şansı gibi imkanlar, destinasyonun alternatif turizm potansiyelinin artmasında öne çıkan hususlar olarak görülebilir.

$\mathrm{Bu}$ çalışmada ulaşılan sonuçlar 1şığında geliştirilen öneriler, şunlardır:

- Bölgenin "UNESCO Dünya Kültür Mirası Geçici Listesi”nde yer alması, firsata dönüştürülebilir. Bunun için özellikle kültürel sebeplerle seyahate çıkan turistlere yönelik kültür turları kapsamında sokak gezilerinin organize edilmesi, doğal ve sanatsal çekiciliklerin sunulmasına ilişkin aktiviteler, yörede yaşayan halkın hayatından izleri yansıtan etkinlikleri kapsayan olayların birleştirilerek turistik bir ürün şekline dönüştürülmesi ve pazara sunulması Ayvalık'a olan turizm talebini artırabilir.

- Ayvalık, yeni yatırımlar için uygun bir bölge olsa da mevcut arazilerin azlığı bölgeye yatırım yapmanın önündeki en büyük engellerden biridir. Bu engeli ortadan kaldırmak için tarım arazileri imara açılmamalıdır (Zeytin ve zeytinyağı açısından son derece büyük öneme sahip olan bu araziler mutlaka koruma altına alınmalıdır). Bunun yerine 2000'in üzerindeki tarihi öneme sahip sivil ve dini mimari yapılar, restore edilmesi teşvik edilerek konaklama tesisi olarak turizme kazandırılabilir ve bölgenin yatak kapasitesi arttırılabilir. Böylelikle bazı eski yapıların şehir merkezinde ortaya çıkardığı kötü görünüm de ortadan kaldırılabilir.

- Ayvalık, iç pazara (yerli turiste) hitap eden bir destinasyondur. Bölgeye gelen yabancı oranı $\% 20$ civarında ve ağırlıklı olarak 1 gece konaklayan uzak doğulu gruplardan oluşmaktadır. Ayvalık'a yabancı turist getirilmesi için yurtdışı fuarlara turizm işletmeleri birlikte katılım sağlamalıdır. Buna ilave olarak hitap edilecek yabancı hedef kitle acenta ve tur operatörleri bölgeye davet edilerek ağırlanabilir ve bölge tanıtımı yapılarak pazarlanması sağlanabilir. 
- Ayvalık destinasyonundaki turizm işletmeleri, genellikle sezonluk çalıştığ i için yaz sezonunda bazı işletmeler yüksek fiyat uygulayabilmektedir. Bu durumun önüne geçilmesi için ilgili kurumlarca (konaklama tesisleri için yerel yönetim, yiyecek-içecek işletmeleri için ticaret ve esnaf odaları) gerekli kontrol ve denetimler daha sık yapılabilir.

- Coğrafi yeri ve doğal yapısı dikkate alındığında Ayvalık, deniz turizminde kayda değer bir zenginliğe sahiptir. Fakat bu zenginlik, kitle turizminin yanı sıra su altı ve su üstü sporları, yat turizmi gibi alternatif turizm türleri geliştirilerek kullanılmalıdır. Yani, yeni turizm türlerinin uygulanmasıyla pazarda sahip olunan pay arttırılabilir. Örneğin zengin su altı kaynaklarına sahip Ayvalık, özellikle kırmızı mercanları ile ünlüdür. Hitap edilecek hedef kitleye ulaşmak ve su altı dalış işletmelerinin yerli ve yabancı acentalar ile anlaşmalar yapmalarını sağlamak için yurt içi ve dışındaki dalış turizmi temalı fuarlara katılım sağlanarak dalış turizmi amacıyla ziyaret edenlerin sayısı arttırılabilir.

- Bölgede düşük fiyatlar uygulayarak haksız rekabete sebep olan ev pansiyonları uyarılabilir ve gerekirse yasal yaptırımlar uygulanarak bu durumun önüne geçilebilir.

- Ayvalık Adaları Tabiat Parkı içinde yer alan 22 adanın turizme kazandırılması için etüt çalışmaları yapılarak çekiciliği arttırılabilir. Örneğin Çiçek Adasında Ocak ve Şubat aylarında açan nergis çiçekleri ile diğer adalardaki endemik bitki türleriyle yeni bir turizm ürünü oluşturularak botanik turizmi kapsamında değerlendirilebilir.

Araştırma sonucunda elde edilen bulgular analiz edilerek bölgedeki yerel paydaşlara, turizm işletmelerine ve ileride bu alanda çalışma yapabilecek araştırmacılara önerilerde bulunulmuştur. $\mathrm{Bu}$ araştırma, aynı zamanda Ayvalık'ta gelecek yıllarda turizm sektöründe yatırım yapmayı planlayan girişimcilere ve yatırımcılara sağladığı güncel verilerle yatırım kararı vermelerinde yol gösterici niteliktedir. Araştırmada verilerin toplandığı bölgenin Balıkesir ilinin Ayvalık ilçesi ile sınırlandırılması, araştırma sonuçlarının genelleştirilmesini engellemektedir. Ancak, bu kısıtlara rağmen araştırma, Ayvalık turizm sektörünün dış çevresi dolayısıyla pazarın genel durumu hakkında fikir vererek ileride yapılacak çalışmalara referans olabilecek niteliktedir. Ayvalık gibi diğer turistik destinasyonların da dış çevre analizi yapılırsa hem o bölgedeki turizm planlamasına katkısı olur hem de o destinasyonlara yatırım yapmayı planlayan girişimcilere turizm sektörünün mevcut durumu ile ilgili bilgiler sunularak rehberlik edilebilir.

\section{Kaynakça}

Babacan, M., Onaran, B., Alkan, G.İ., Bozkurt, Ö., Eriş, E.D. ve Bulut, Z.A. (2017). İşletme yönetimi. Ankara: Detay Yayıncılık.

Bayın, G. (2014). Sistem yaklaşımı bakış açısıyla sağlık kurumlarında dış çevre analizi. Çankırı Karatekin Üniversitesi İktisadi ve İdari Bilimler Fakültesi Dergisi, 4(2), 99-120.

Bedük, A., Zerenler, M. ve Soysal, A. (2007). Değişen Dünya'da yeni Yönetim Modelleri'nin turizm sektörü'nde kullanılması ve tanıtım stratejileri'nin belirlenmesi. Selçuk Üniversitesi Sosyal Bilimler Enstitüsü Dergisi, (20), 135-162.

Buhalis, D. (2000). Marketing the Competitive Destination of the future. Tourism Management, 21(1), 97-116.

Camison, C. ve Fores, B. (2015). Is tourism firm competitiveness driven by different internal or external specific factors?: New empirical evidence from Spain. Tourism Management, (48), 477-499.

Canbaz, S. (2014). Kobi'lerde stratejik planlama ve karar alma sürecinde yönetim bilgi sistemlerinin rolü ve önemi: Edirne'de bir araştırma (Doktora tezi). Trakya Üniversitesi, Edirne. 
Coşar, Y. (2006). Konaklama işletmelerinin rekabet gücü ve rekabet gücünü belirlemeye yönelik İzmir Illi'nde dört ve beş ylldızlı otellerde bir uygulama (Yüksek lisans tezi). Dokuz Eylül Üniversitesi, İzmir.

Çoşkun, R., Altunışık, R., Bayraktroğlu, S. ve Yıldırım, E. (2015). Sosyal bilimlerde araştırma yöntemleri. Sakarya: Sakarya Yayınc1lık.

Dwyer, L., Edwards, D., N., Mistilis, Roman, C. ve Scott, N. (2009). Destination and enterprise management for a tourism future. Tourism Management, 30(1), 63-74.

Fettahlıŏlu, Ö.O., Birin, C. \& Çiçeklioğlu, H. (2016). İ̧sletmelerin çevresel unsurlarına yönelik süreç geliştirme. 3rd International Congress On Social Sciences, China To Adriatic Congress Book, 746.

Franch, M., Martini, U., \& Tommasini, D. (2003). Hypothesis of destination management in the Alps through the analysis of regional tourist boards. In Atti del convegno XII International Symposium on Tourism and Leisure, Barcelona, 3-4.

Göral, R. (2014). Turizm işletmelerinde stratejik yönetim. Ankara: Detay Yayınc1lık.

Güçlü, N. (2003). Stratejik yönetim. Gazi Eğitim Fakültesi Dergisi, 23(2), 61-85.

Güripek, E. (2013). Turizm destinasyonlarının rekabet gücünün artırılmasında stratejik destinasyon yönetimi: Çeşme Alaçatı destinasyonu üzerine bir uygulama (Doktora Tezi). Dokuz Eylül Üniversitesi, İzmir.

Hassan, S. S. (2000). Determinants of market competitiveness in an environmentally sustainable tourism industry. Journal of Travel Research, (38), 239-245.

Indris, S. ve Primiana, I. (2015). Internal and external environment analysis on the performance of small and medium industries (Smes) in Indonesia. International Journal Of Scientific \& Technology Research, 4(4), 2277-8616.

İlban, M. O. (2007). Destinasyon pazarlamasında marka imajı ve seyahat acentalarında bir araştırma (Doktora tezi). Balıkesir Üniversitesi, Balıkesir.

Johan, A.W., Baga, L.M. and Asmara, A. (2018). competitiveness 1mprovement strategy formulation on individual hotel: Case Of Xyz Hotel At City Of Bogor. European Journal of Hospitality and Tourism Research, 6(2), 1-15.

Karagiannopoulos, G.D., Georgopoulos, N. and Nikolopoulos, K. (2005). Fathoming Porter's five forces model in the internet era. Emerald Insight, info, 7(6), 66-76.

Kayabaş1, A. (2012). İşletmelerin rekabet gücünün geliştirilmesinde lojistik faaliyetlerin performansının arttırlması: üretim işletmeleri üzerine bir uygulama (Doktora tezi). Dokuz Eylül Üniversitesi, İzmir.

Koçoğlu, D. ve Serinkan, C. (2012). Türkiye'de yükseköğretimin dış çevre analizi ve Pamukkale Üniversitesi'nin rekabet edebilirliği. Atatürk Üniversitesi İktisadi ve İdari Bilimler Dergisi, 26(2), 39-64.

Mathooko, F. M. ve Ogutu, M. (2015). Porter's five competitive forces framework and other factors that influence the choice of response strategies adopted By Public Universities in Kenya. International Journal of Educational Management, 29(3), 334-354.

Ofluoğlu, G., Arslan, G. ve Aydemir, S. (2006). Küreselleşme sürecinde işletmelerde dış çevrenin analizi. Катu-IŞ, 8(4).

Önen, V. (2017). Porter' in beş güç metodu ile Türkiye havayolu yolcu pazarı rekabetçi analizi. International Journal of Academic Value Studies, 3(9), 371-393 (ISSN:2149-8598). 
Özdemir, E. G. ve Y1lmaz, G. (2016). Konaklama işletmelerinin rekabet gücünü belirleyen faktörler üzerine Nevşehir ilinde bir uygulama. Journal of Multidisciplinary Academic Tourism, 1(1), 61-80.

Özdemir, G. (2007). Destinasyon yönetimi ve pazarlama temelleri İzmir için bir destinasyon modeli önerisi (Doktora tezi). Dokuz Eylül Üniversitesi, İzmir.

Sucu, M. E. (2010). Kobi'lerde stratejik yönetim ve bir araştırma (Yüksek lisans tezi). Pamukkale Üniversitesi, Denizli.

T.C. Ayvalık Belediye Başkanlığı.

T.C. Kültür ve Turizm Bakanlığ1 (2018). Konaklama istatistikleri, http://yigm.kulturturizm.gov.tr/TR-201122/belediye-belgeli-tesis-konaklamaistatistikleri.html ve http://yigm.kulturturizm.gov.tr/TR-201121/isletme-bakanlik-belgelitesis-konaklama-istatistikleri.html (Erişim tarihi: 09.11.2018).

T.C. Kültür ve Turizm Bakanlığı (2019). Turizm işletme belgeli tesisler, http://yigm.kultur.gov.tr/TR-9579/turizm-tesisleri.html (Erişim tarihi: 08.02.2019).

T.C. Kültür ve Turizm Bakanlığı, Ayvalık Turizm Danışma Bürosu Resmi İnternet Sitesi (2018). Genel Bilgiler, http://www.ayvalikturizmdanismaburosu.gov.tr/TR-142815/genelbilgiler.html (Erişim tarihi: 09.11.2018).

T.C. Kültür ve Turizm Bakanlığı. Ayvalık Turizm Danışma Bürosu.

T.C. Tarım ve Orman Bakanlığı, Doğa Koruma ve Milli Parklar Genel Müdürlüğü, Ayvalık Adaları Tabiat Parkı Resmi İnternet Sitesi (2018). Ayvalık doğal çevre bilgileri, http://ayvalikadalari.tabiat.gov.tr/ (Erişim tarihi: 09.11. 2018).

Türkay, O., Solmaz, S. A. and Şengül, S. (2011). Strategic Analysis of the External Environment and the Importance of the Information: Research on Perceptions of Hotel Managers. Procedia Social and Behavioral Sciences, 24, 1060-1069.

UNESCO - Birleşmiş Milletler Eğitim, Bilim ve Kültür Kurumu (2019). Ayvalık Industrial Landscape, http://whc.unesco.org/en/tentativelists/6243/ (Erişim tarihi: 08.02.2019).

UZZK - Ulusal Zeytin ve Zeytinyağı Konseyi (2019). Balıkesir İli 2016/2017 Sezonu Zeytin ve Zeytinyağı Rekoltesi, http://uzzk.org/Belgeler/2016_2017_REKOLTE_BALIKESIR.PDF (Erişim tarihi: 08.02.2019).

Ülgen, H. ve Mirze, S.K. (2018). İşletmelerde stratejik yönetim. İstanbul: Beta Basın Yayım.

Voiculet, A., Belu, N. Parpandel, D. E. ve Rizea, I. C. (2010). The impact of external environment on organizational development strategy.

Wang, C.-H., Chen, K-Y., ve Chen, S-C. (2012). Total quality management, market orientation and hotel performance: the moderating effects of external environmental factors. International Journal of Hospitality Management, 31, 119-129.

Yılmaz, N. (2012). Stratejik perspektifte yenilikçilik ve kurumsal girişimcilik temelli büyüme: Türkiye şeker sektörü örneği (Doktora tezi). Selçuk Üniversitesi, Konya.

Yiğit, S ve Yiğit A. M. (2011). Stratejik yönetimde dış çevre analizi: Kobi'ler ve büyük işletmeler arasında bir karşılaştırma. Erciyes Üniversitesi İktisadi ve İdari Bilimler Fakültesi Dergisi, 120(38), 119-136.

Zengin, B. ve Uyar, H. (2012). Türk turizm ve otelcilik sektöründe rekabet ve rekabeti etkileyen faktörlerin otel işletmelerine yönelik olarak değerlendirilmesi. Bartın Üniversitesi İ.I.B.F. Dergisi, 3(5), 1-22. 


\section{ETIKK ve BİLIMSEL İLKELER SORUMLULUK BEYANI}

$\mathrm{Bu}$ çalışmanın tüm hazırlanma süreçlerinde etik kurallara ve bilimsel atıf gösterme ilkelerine riayet edildiğini yazar(lar) beyan eder. Aksi bir durumun tespiti halinde Afyon Kocatepe Üniversitesi Sosyal Bilimler Dergisi'nin hiçbir sorumluluğu olmayıp, tüm sorumluluk makale yazarlarına aittir. 